\title{
SISTEM PENGENALAN NAGHAM ADZAN MELALUI SUARA MENGGUNAKAN METODE DISCRETE WAVELET TRANSFORM (DWT) DAN MELLIN TRANSFORM
}

\author{
Rizal, Lidya Rosnita,Ikramina, \\ Teknik Informatika Universitas Malikussaleh Lhokseumawe \\ Jl. Cot Tgk Nie-Reulet, Aceh Utara, 141 Indonesia \\ email :ikramina.nana@gmail.com
}

\begin{abstract}
ABSTRAK
Adzan dan Iqamah menjadi penanda waktu masuknya melaksanakan rukun islam yang kedua. Ketika muazzin mengumandangkan azan pada waktu-waktu tertentu dengan suara yang merdu dengan ciri khas nagham yang berbeda-beda.Nagham adalah kata yang berasal dari bahasa Arab yang artinya lagu/irama. Kata nagham yang akhirnya kemudian dirangkai dengan Al-Qur'an menjadi nagham Al-Qur'an yang artinya melagukan Al-Qur'an, bisa juga disebut dengan Tahsin As-Shout dalam membaca Al-Qur'an (membaguskan suara dalam membaca AlQur'an). Banyak masyarakat yang belum mengetahui jenis-jenis nagham yang sering digunakan oleh muazzin dan sangat disayangkan kejadian seperti ini terjadi pada beberapa remaja bahkan sebagian orang dewasa yang belum paham tentang nagham itu sendiri. Hal tersebut yang menjadikan penulis tertarik untuk membuat sebuah sistem yang dapat mengenali nagham apa yang digunakan saat adzan melalui sample suara adzan yang kita masukkan. Sistem ini memudahkan kita dalam belajar jenis nagham adzan, maka dari itu penulis tertarik mengambil judul Pengenalan Nagham Adzan Melalui Suara Menggunakan Discrete Wavelet Transform dan MellinTransform.Discrete Wavelet Transform dan MellinTransform ini digunakan untuk mencari nilai frekuensi pada sinyal suara.Hasil penelitian menunjukkan bahwa sistem Perbandingan Kinerja Algoritma Discrete Wavelet Transform (DWT)Dan Mellin Transform untuk pengenalan nagham suara adzan, memiliki kisaran true detection untuk algoritma Discrete Wavelet Transform sebesar 73,33\% dan Mellin Transform sebesar $80 \%$.
\end{abstract}

Kata kunci : Al-Quran, Nagham, Discrete Wavelet Transform, Mellin Transform 
TECHSI: Vol. 10, No. 2, Oktober 2018

\section{PENDAHULUAN}

Islam merupakan salah satu agama resmi di Indonesia, bahkan agama Islam di Indonesia menjadi mayoritas di dunia yang menjadikan Islam sebagai agama terbesar kedua di dunia setelah agama Kristen.Islam cukup kuat dengan dalil yang telah disampaikan oleh Allah di dalam ayat-ayat suci Al-quran begitu pula dengan sunnahsunnahnya.

Adzan dan Iqamah menjadi penanda waktu masuknya melaksanakan rukun islam yang kedua. Ketika muazzin mengumandangkan adzan pada waktu-waktu tertentu dengan suara yang merdu dengan ciri khas nagham yang berbeda-beda.Nagham adalah kata yang berasal dari bahasa Arab yang artinya lagu/irama.Populernya istilah nagham berasal dari para Qori'/ para Syech/ dari Mesir yang pernah mengajarkan ilmunya di Indonesia pada tahun 1973. Kata nagham yang akhirnya kemudian dirangkai dengan AlQur'an menjadi nagham Al-Qur'an yang artinya melagukan Al-Qur'an, bisa juga disebut dengan Tahsin As-Shout dalam membaca Al-Qur'an (membaguskan suara dalam membaca Al-Qur'an).

Banyak masyarakat yang belum mengetahui jenis-jenis nagham yang sering digunakan oleh muazzin dan sangat disayangkan kejadian seperti ini terjadi pada beberapa remaja bahkan sebagian orang dewasa yang belum paham tentang nagham itu sendiri. Hal tersebut yang menjadikan penulis tertarik untuk membuat sebuah sistem yang dapat mengenali nagham apa yang digunakan saat adzan melalui sample suara adzan yang kita masukkan. Sistem ini memudahkan kita dalam belajar jenis nagham adzan.Berdasarkan uraian permasalahan di atas, maka dari itu penulis tertarik mengambil judul "Pengenalan Nagham Adzan Melalui Suara Menggunakan Discrete Wavelet Transform dan MellinTransform".

\section{METODOLOGI PENELITIAN}

\subsection{DISCRETE WAVELET TRANSFORM (DWT)}

Discrete Wavelet Transform (DWT) merupakan dekomposisi citra pada frekuensi subband citra tersebut. Komponen subband transformasi wavelet dihasilkan dengan cara penurunan level dekomposisi. Transformasi adalah proses merepresentasikan suatu sinyal ke dalam domain / kawasan lain sehingga mudah untuk dianalisa..Tujuan dari transformasi adalah untuk lebih menonjolkan sifat atau karakteristik sinyal tersebut.Wavelet diartikan sebagai small wave atau gelombang singkat. Transformasi wavelet akan menkonversi 
suatu sinyal ke dalam sederetan wavelet. Gelombang singkat tersebut merupakan fungsi basis yang terletak pada waktu berbeda.

Transformasi wavelet merupakan perbaikan dari transformasi fourier. Transformasi wavelet selain mampu memberikan informasi frekuensi yang muncul, juga dapat memberikan informasi tentang skala atau durasi atau waktu.wavelet dapat digunakan untuk menganalisa suatu bentuk gelombang (sinyal) sebagai kombinasi dari waktu (skala) dan frekuensi.Dekomposisi perataan (averages) dan pengurangan (differences) memegang peranan penting untuk memahami transformasi wavelet. Perataan dilakukan dengan menghitung nilai rata-rata 2 pasang data dengan rumus :

Rumus DWT untuk menghitung nilai rata-rata :

$$
p=\frac{x+y}{2}
$$

Sedangkan pengurangan dilakukan dengan rumus :

$$
p=\frac{x-y}{2}
$$

Keterangan:

$\mathrm{x}=$ Nilai koefisien piksel $\mathrm{x}$

$\mathrm{y} \quad=$ Nilai koefisien piksel $\mathrm{y}$

\subsection{MELLIN TRANSFORM}

Dalam matematika, transformasi mellin adalah transformasi integral yang dapat di anggap sebagai versi perkalian dari dua sisi transformasi Laplace.Integral transformasi ini adalah berkaitan erat dengan teori seri dirichlet dan sering digunakan di nomor teori dan teori asimtotik, itu berkaitan erat dengan transform Laplace. Transformasi Fourier, teori fungsi gamma dan fungsi khusus bersekutu.

Transformasi Mellin adalah :

$$
\boldsymbol{\varphi}(\boldsymbol{s})=\sum_{k=0}^{n-1} x^{s-1} f(x)
$$

Keterangan:

$$
\begin{array}{ll}
\boldsymbol{\varphi ( s )} & =\text { Transformasi Mellin } \\
\mathrm{x} & =\text { Index Transformasi } \\
\mathrm{S} & =\text { Index Sinyal } \\
\mathrm{f}(\mathrm{x}) & =\text { Frekuensi }
\end{array}
$$

\subsection{SKEMA SISTEM}

Skema sistem digunakan untuk mengilustrasikan beberapa informasi tentang file suara yang terkait dengan aplikasi yang akan dibangun. Dari 
beberapa pengambilan sample yang sudah dilakukan semuanya akandiilustrasikan dalam bentuk skema yang berkaitan dengan sistem yang berkaitan antara satu dengan lainnya. Skema sistem adalah struktur dan mekanisme untuk menghubungkan sekumpulan unsur atau elemen yang saling berkaitan dan saling mempengaruhi dalam melakukan kegiatan bersama untuk mencapai suatu tujuan.

Sistem dapat didefinisikan sebagai suatu kumpulan atau himpunan dari unsur, komponen, atau variabel yang terorganisasi, saling berinteraksi, saling tergantung satu sama lain dan terpadu. Unsur-unsur yang mewakili suatu sistem secara umum adalah masukan (input), pengolahan (processing), dan keluaran (output) (Tata Sutabri, 2012).

\subsection{SKEMA DISKRIT WAVELET TRANSFORM}

Skema diskritwavelet transform adalah racangan flowchart yang menggambarkan proses penerapan dari rumus metode tersebut untuk mengetahui hasil nilai perhitungan sistematis berdasarkan deteksi suara yang telah diinput.

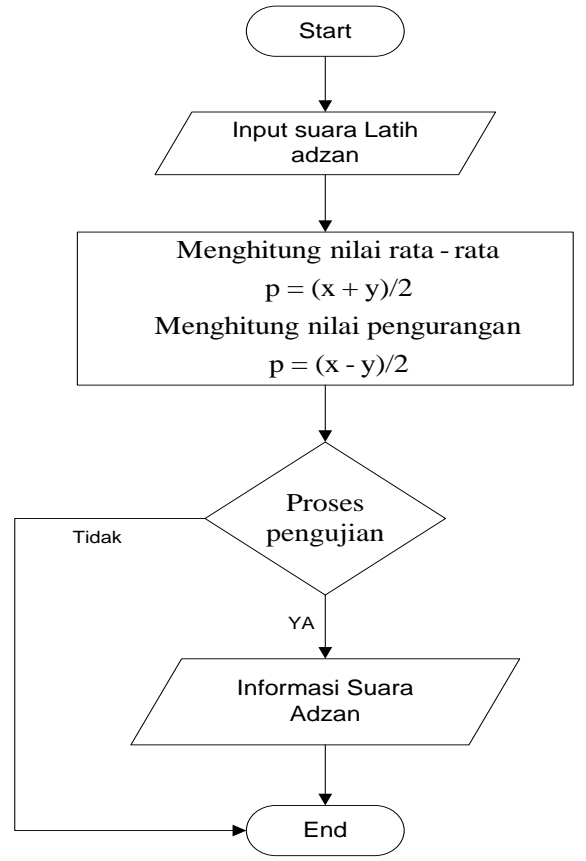

Gambar 2.1 Skema DiskritWavelet Transform 


\subsection{SKEMA MELLIN TRANSFORM}

Skema mellintransform adalah racangan flowchart yang menggambarkan proses penerapan dari rumus metode tersebut untuk mengetahui hasil nilai perhitungan sistematis berdasarkan deteksi suara yang telah diinput.

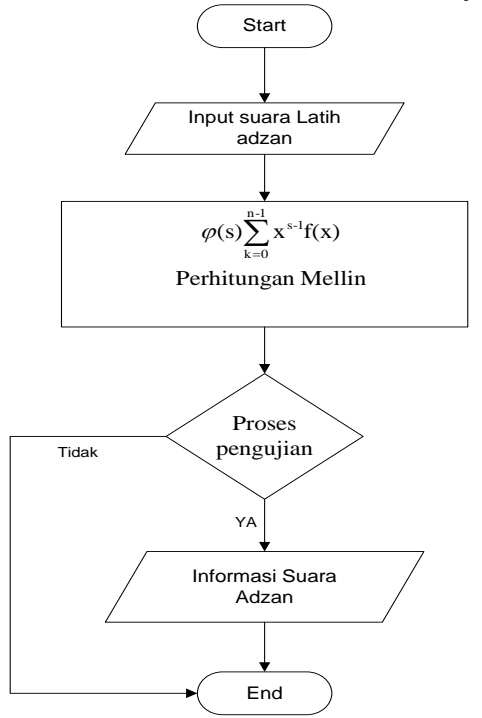

Gambar 2.2 Skema Mellin Transform

\section{ANALISA DAN PEMBAHASAN}

\subsection{PERHITUNGAN MANUAL}

1. Perhitungan Manual Discrete Wavelet Transform (DWT)

Dekomposisi perataan (averages) dan pengurangan (differences) memegang peranan penting untuk memahami transformasi Wavelet. Untuk memahami dekomposisi perataan dan pengurangan ini, berikut adalah contoh transformasi wavelet 1 dimensi dengan dimensi 8 .

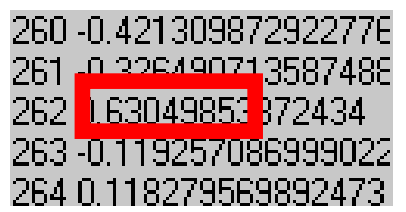

\begin{tabular}{|l|l|l|l|l|l|l|l|}
\hline 6 & 3 & 0 & 4 & 9 & 8 & 5 & 3 \\
\hline
\end{tabular}

Gambar 3.1 contoh nilai frekuensi pada sistem 
Perataan dilakukan dengan menghitung nilai rata-rata 2 pasang data dengan rumus :

$$
p=\frac{x+y}{2}
$$

Sedangkan pengurangan dilakukan dengan rumus :

$$
p=\frac{x-y}{2}
$$

Keterangan:

$\mathrm{x}=$ Nilai koefisien pixsel $\mathrm{x}$

$\mathrm{y} \quad=$ Nilai koefisien pixsel $\mathrm{y}$

Hasil proses perataan untuk contoh diatas adalah :

$\frac{6 \quad 3}{4,5} \frac{0 \quad 4}{2} \frac{9}{8,5} \frac{5 \quad 3}{4}$

Sedangkan hasil proses pengurangannya adalah :

$\frac{6 \quad 3}{1,5} \frac{0 \quad 4}{-2} \frac{9 \quad 8}{0,5} \frac{5 \quad 3}{1}$

Sehingga hasil proses dekomposisi perataan dan pengurangan terhadap contoh diatas adalah :

\begin{tabular}{|l|l|l|l|l|l|l|l|}
\hline 4,5 & 2 & 8,5 & 4 & 1,5 & -2 & 0,5 & 1 \\
\hline
\end{tabular}

Gambar 4.20 Hasil Proses Transformasi Perataan

Dan Pengurangan Dari Gambar 4.19

Perhatikan pada hasil diatas, hasil perataan diletakkan di bagian depan kemudian diikuti dengan hasil proses pengurangan. Untuk mendapat nilai semula dari hasil dekomposisi maka dapat dilakukan proses rekonstruksi atau sintesis seperti ditunjukkan pada gambar 4.21

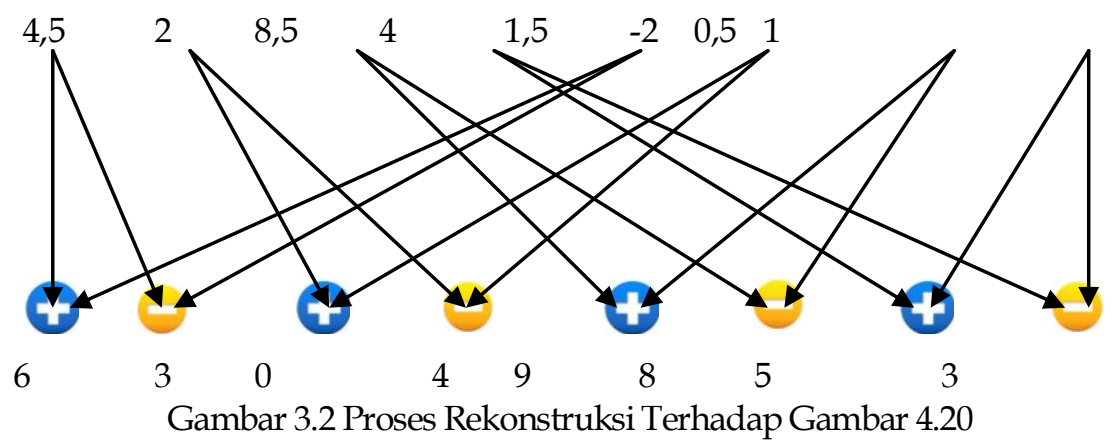

Tampak pada gambar 3.2, hasil proses rekonstruksi tepat sama dengan nilai semula. Proses dekomposisi yang dilakukan di atas hanya 1 kali 
(1 level ) saja. Gambar 4.22 menunjukkan proses transformasi penuh dan berhenti setelah tersisa 1 pixel saja.
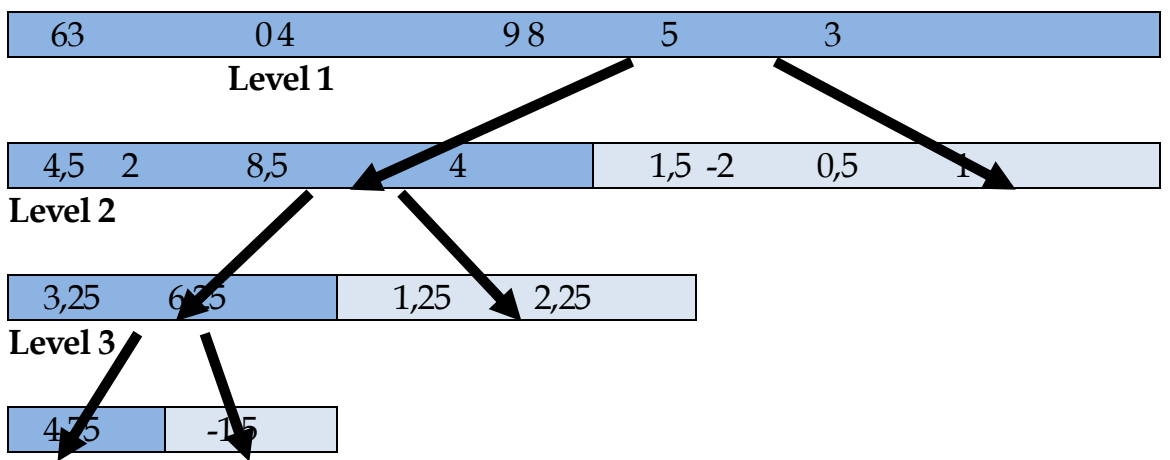

Gambar 3.3 Proses perataan dan pengurangan dengan dekomposisi penuh (3 level)

Pada setiap level, proses dekomposisi hanya dilakukan pada bagian hasil proses perataan dan hasil proses dekomposisi adalah gabungan dari proses perataan sengan seluruh hasil proses pengurangan. Nilai hasil dekomposisi penuh di atas adalah :

\begin{tabular}{|l|llllll|}
\hline 4,75 & $1^{-1,5}$ & 1,25 & 2,25 & 1,5 & -2 & 0,5 \\
\hline
\end{tabular}

Gambar 3.4 Hasil Proses dekomposisi penuh

2. Perhitungan Manual Mellin Transform

Berikut ini adalah contoh penjabaran rumus transpormasi mellin: Rumus Mellin:

$$
\varphi(s)=\sum_{x=0}^{n-1} x^{s-1} f(x)
$$

Keterangan:

$$
\begin{array}{ll}
\boldsymbol{\varphi}(\boldsymbol{s}) & =\text { Transformasi Sinyal } \\
\mathrm{x} & =\text { Index Transformasi } \\
\mathrm{s} & =\text { Index Sinyal } \\
\mathrm{f}(\mathrm{x}) & =\text { Frekuensi }
\end{array}
$$

Berikut adalah contoh transformasi mellin : 
a. Mencari Energi Allahu

Dik: $x \quad=0,1,2,3,4,5,6,7$

$$
\begin{array}{cl}
\mathrm{S} & =0,1,2,3,4,5,6,7 \\
\mathrm{~F}(\mathrm{x}) & =6,3,0,4,9,8,5,3
\end{array}
$$

Penyelesaian :

$$
\begin{aligned}
& \boldsymbol{\varphi}(0) \quad=\left(0^{0-1} .6\right)+\left(1^{0-1} .3\right)+\left(2^{0-1} .0\right)+\left(3^{0-1} .4\right)+\left(4^{0-1} .9\right)+\left(5^{0-1} .8\right) \\
& +\left(6^{0-1} .5\right)+\left(7^{0-1} \cdot 3\right) \\
& \boldsymbol{\varphi}(0) \quad=0+3+0+1,33+2,25+1,6+0,83+0,42=9,43 \\
& \boldsymbol{\varphi}(1) \quad=\left(0^{1-1} .6\right)+\left(1^{1-1} .3\right)+\left(2^{1-1} .0\right)+\left(3^{1-1} .4\right)+\left(4^{1-1} .9\right)+\left(5^{1-1} .8\right) \\
& +\left(6^{1-1} .5\right)+\left(7^{1-1} .3\right) \\
& \boldsymbol{\varphi}(1) \quad=6+3+0+4+9+8+5+3=38 \\
& \boldsymbol{\varphi}(2) \quad=\left(0^{2-1} .6\right)+\left(1^{2-1} .3\right)+\left(2^{2-1} .0\right)+\left(3^{2-1} .4\right)+\left(4^{2-1} .9\right)+\left(5^{2-1} .8\right) \\
& +\left(6^{2-1} .5\right)+(72-1.3) \\
& \boldsymbol{\varphi}(2) \quad=0+3+0+12+36+40+30+21=142 \\
& \boldsymbol{\varphi}(3) \quad=\left(0^{3-1} \cdot 6\right)+\left(1^{3-1} \cdot 3\right)+\left(2^{3-1} .0\right)+\left(3^{3-1} .4\right)+\left(4^{3-1} .9\right)+\left(5^{3-1} \cdot 8\right) \\
& +\left(6^{3-1} .5\right)+\left(7^{3-1} \cdot 3\right) \\
& \boldsymbol{\varphi}(3) \quad=0+3+0+36+144+200+180+147=710 \\
& \varphi(4) \quad=\left(0^{4-1} .6\right)+\left(1^{4-1} .3\right)+\left(2^{4-1} .0\right)+\left(3^{4-1} .4\right)+\left(4^{4-1} .9\right)+\left(5^{4-1} .8\right) \\
& +\left(6^{4-1} .5\right)+\left(7^{4-1} \cdot 3\right) \\
& \boldsymbol{\varphi}(4) \quad=0+3+0+108+576+1000+1080+1029=3796 \\
& \boldsymbol{\varphi}(5) \quad=\left(0^{5-1} .6\right)+\left(1^{5-1} .3\right)+\left(2^{5-1} .0\right)+\left(3^{5-1} .4\right)+\left(4^{5-1} .9\right)+\left(5^{5-1} .8\right) \\
& +\left(6^{5-1} .5\right)+(75-1.3) \\
& \boldsymbol{\varphi}(5) \quad=0+3+0+324+2404+5000+6480+7203=21414 \\
& \boldsymbol{\varphi}(6) \quad=\left(0^{6-1} .6\right)+\left(1^{6-1} .3\right)+\left(2^{6-1} .0\right)+\left(3^{6-1} .4\right)+\left(4^{6-1} .9\right)+\left(5^{6-1} .8\right) \\
& +\left(6^{6-1} .5\right)+\left(7^{6-1} \cdot 3\right) \\
& \boldsymbol{\varphi}(6) \quad=0+3+0+972+9216+25000+38880+50421=124492 \\
& \boldsymbol{\varphi}(7) \quad=\left(0^{7-1} .6\right)+\left(1^{7-1} .3\right)+\left(2^{7-1} .0\right)+\left(3^{7-1} .4\right)+\left(4^{7-1} .9\right)+\left(5^{7-1} .8\right) \\
& +\left(6^{7-1} \cdot 5\right)+\left(7^{7-1} \cdot 3\right) \\
& \boldsymbol{\varphi}(7) \quad=0+3+0+2916+36864+125000+233280+352947 \\
& =751010
\end{aligned}
$$

$$
\begin{aligned}
\text { Energi mellin } & =9,43+38+142+710+3796+21414+124492 \\
& +751010 \\
& =901611,43
\end{aligned}
$$

\subsection{Hasil Unjuk Kerja Sistem}

Pengukuran unjuk kerja system ini memiliki jumlah 3 sample suara pada proses pelatihan dan 5 sample suara pada proses pengujian diuji dengan 5 sample suara untuk tiap-tiap adzan. 
Tabel 4.5 Hasil Unjuk Kerja Metode Discrete Wavelet Transform

\begin{tabular}{|c|c|c|c|c|c|c|}
\hline $\begin{array}{c}\text { Jenis } \\
\text { Irama }\end{array}$ & $\begin{array}{c}\text { Jumlah } \\
\text { suara } \\
\text { pelatih } \\
\text { an }\end{array}$ & $\begin{array}{c}\text { Jumlah } \\
\text { Suara } \\
\text { Pengujia } \\
\text { n }\end{array}$ & $\begin{array}{c}\text { Jumlah } \\
\text { Suara } \\
\text { yang } \\
\text { Terdetek } \\
\text { si }\end{array}$ & $\begin{array}{c}\text { False } \\
\text { Posit } \\
\text { ive } \\
\text { Rate }\end{array}$ & $\begin{array}{c}\text { Detecti } \\
\text { on } \\
\text { Rate }\end{array}$ & Persentase \\
\hline $\begin{array}{c}\text { Suara } \\
\text { Adzan } \\
\text { Irama } \\
\text { Bayyati }\end{array}$ & 1 & 5 & 4 & 1 & 4 & $80 \%$ \\
\hline $\begin{array}{c}\text { Suara } \\
\text { Adzan } \\
\text { Irama } \\
\text { Nahawa }\end{array}$ & 1 & 5 & 3 & 2 & 3 & $60 \%$ \\
\hline $\begin{array}{c}\text { Suara } \\
\text { Adzan } \\
\text { Irama } \\
\text { Mansoor } \\
\text { Al- }\end{array}$ & 1 & 5 & 4 & 1 & 4 & $80 \%$ \\
Zahraany & & & & & & \\
\hline
\end{tabular}

Hasil pengujian tabel 4.5 menunjukkan bahwa true detection pada masing-masing suara adzan sangat dipengaruhi oleh banyaknya sampel suara pelatihan.Hal ini terjadi karena sampel suara adzan dikenali jika sampel suara yang diuji mempunyai sampling pola suara yang mirip dengan sampling pola suara latih.Untuk mencari nilai presentasi kebenarannya, jumlah detection rate dibagi dengan jumlah suara pengujian dan kemudian dikali 100.

Tabel 4.6 Hasil Unjuk Kerja Metode Mellin Transform

\begin{tabular}{|c|c|c|c|c|c|c|}
\hline $\begin{array}{c}\text { Jenis } \\
\text { Irama }\end{array}$ & $\begin{array}{c}\text { Jumlah } \\
\text { suara } \\
\text { pelatih } \\
\text { an }\end{array}$ & $\begin{array}{c}\text { Jumlah } \\
\text { Suara } \\
\text { Pengujia } \\
\mathbf{n}\end{array}$ & $\begin{array}{c}\text { Jumlah } \\
\text { Suara } \\
\text { yang } \\
\text { Terdetek } \\
\text { si }\end{array}$ & $\begin{array}{c}\text { False } \\
\text { Posit } \\
\text { ive } \\
\text { Rate }\end{array}$ & $\begin{array}{c}\text { Detecti } \\
\text { on } \\
\text { Rate }\end{array}$ & $\begin{array}{c}\text { Persenta } \\
\text { se }\end{array}$ \\
\hline $\begin{array}{c}\text { Suara } \\
\text { Adzan } \\
\text { Irama } \\
\text { Bayyati }\end{array}$ & 1 & 5 & 4 & 1 & 4 & $80 \%$ \\
\hline Suara & 1 & 5 & 4 & 1 & 4 & $80 \%$ \\
\hline
\end{tabular}




\begin{tabular}{|c|c|c|c|c|c|c|}
\hline $\begin{array}{c}\text { Adzan } \\
\text { Irama } \\
\text { Nahawa }\end{array}$ & & & & & & \\
\hline $\begin{array}{c}\text { Suara } \\
\text { Adzan } \\
\text { Irama } \\
\text { Mansoor } \\
\text { Al- } \\
\text { Zahraany }\end{array}$ & 1 & 5 & 4 & 1 & 4 & $80 \%$ \\
\hline
\end{tabular}

Hasil pengujian tabel 4.6 menunjukkan bahwa true detection pada masing-masing suara adzan sangat dipengaruhi oleh banyaknya sampel suara pelatihan.Hal ini terjadi karena sampel suara adzan dikenali jika sampel suara yang diuji mempunyai sampling pola suara yang mirip dengan sampling pola suara latih.Untuk mencari nilai presentasi kebenarannya, jumlah detection rate dibagi dengan jumlah suara pengujian dan kemudian dikali 100.

Tabel 4.7 Hasil Unjuk Kerja Metode Discrete Wavelet Transform Sistem Pengenalan nagham adzan melalui suara (untuk pengenalan selain suara

\begin{tabular}{|c|c|c|c|c|c|c|c|}
\hline \multicolumn{8}{|c|}{ adzan) } \\
\hline $\begin{array}{l}\text { Jenis } \\
\text { Irama } \\
\text { Adzan } \\
\text { Latih }\end{array}$ & $\begin{array}{l}\text { Jenis } \\
\text { Surah } \\
\text { Yang } \\
\text { diuji }\end{array}$ & $\begin{array}{c}\text { Jumlah } \\
\text { Suara } \\
\text { Pelatiha } \\
\text { n }\end{array}$ & \begin{tabular}{|c} 
Jumla \\
h \\
Suara \\
Penguj \\
ian
\end{tabular} & $\begin{array}{c}\text { Jumlah } \\
\text { Suara } \\
\text { Yang } \\
\text { Terdete } \\
\text { ksi }\end{array}$ & $\begin{array}{c}\text { False } \\
\text { Positive } \\
\text { Rate }\end{array}$ & $\begin{array}{l}\text { Detection } \\
\text { Rate }\end{array}$ & $\begin{array}{c}\text { Persenta } \\
\text { se }\end{array}$ \\
\hline $\begin{array}{c}\text { Suara } \\
\text { Adzan } \\
\text { Irama } \\
\text { Bayyati }\end{array}$ & $\begin{array}{c}\text { Surah } \\
\text { Al- } \\
\text { Ikhlash } \\
\text { Irama } \\
\text { Bayyati }\end{array}$ & 1 & 5 & 3 & 2 & 3 & $60 \%$ \\
\hline $\begin{array}{c}\text { Suara } \\
\text { Adzan } \\
\text { Irama } \\
\text { Nahawa }\end{array}$ & $\begin{array}{c}\text { Surah } \\
\text { Al- } \\
\text { Ikhlash } \\
\text { Irama } \\
\text { Nahaw } \\
\text { a }\end{array}$ & 1 & 5 & 2 & 3 & 2 & $40 \%$ \\
\hline
\end{tabular}




\begin{tabular}{|c|c|c|c|c|c|c|c|}
\hline $\begin{array}{l}\text { Suara } \\
\text { Adzan } \\
\text { Irama } \\
\text { Mansoor } \\
\text { Al- } \\
\text { Zahraany }\end{array}$ & $\begin{array}{l}\text { Surah } \\
\text { Al- } \\
\text { Ikhlash } \\
\text { Irama } \\
\text { Manso } \\
\text { or }\end{array}$ & 1 & 5 & 3 & 2 & 3 & $60 \%$ \\
\hline
\end{tabular}

Hasil pengujian tabel 4.7 menunjukkan bahwa true detection pada masing-masing suara adzan sangat dipengaruhi oleh banyaknya sampel suara pelatihan.Hal ini terjadi karena sampel suara adzan dikenali jika sampel suara yang diuji mempunyai sampling pola suara yang mirip dengan sampling pola suara latih.Untuk mencari nilai presentasi kebenarannya, jumlah detection rate dibagi dengan jumlah suara pengujian dan kemudian dikali 100.

Tabel 4.8 Hasil Unjuk Kerja Metode Mellin Transform Sistem Pengenalan nagham adzan melalui suara (untuk pengenalan selain suara adzan)

\begin{tabular}{|c|c|c|c|c|c|c|c|}
\hline $\begin{array}{c}\text { Jenis } \\
\text { Irama } \\
\text { Adzan } \\
\text { Latih }\end{array}$ & $\begin{array}{l}\text { Jenis } \\
\text { Surah } \\
\text { Yang } \\
\text { diuji }\end{array}$ & $\begin{array}{l}\text { Jumlah } \\
\text { Suara } \\
\text { Pelatiha } \\
\text { n }\end{array}$ & $\begin{array}{l}\text { Jumlah } \\
\text { Suara } \\
\text { Pengujia } \\
\text { n }\end{array}$ & \begin{tabular}{|} 
Jumlah \\
Suara \\
Yang \\
Terdeteks \\
i \\
\end{tabular} & $\begin{array}{c}\text { False } \\
\text { Positiv } \\
\text { e Rate }\end{array}$ & $\begin{array}{l}\text { Detecti } \\
\text { on Rate }\end{array}$ & Persentase \\
\hline $\begin{array}{l}\text { Suara } \\
\text { Adzan } \\
\text { Irama } \\
\text { Bayyati }\end{array}$ & $\begin{array}{l}\text { Surah } \\
\text { Al- } \\
\text { Ikhlash } \\
\text { Irama } \\
\text { Bayyati } \\
\end{array}$ & 1 & 5 & 4 & 1 & 4 & $80 \%$ \\
\hline $\begin{array}{c}\text { Suara } \\
\text { Adzan } \\
\text { Irama } \\
\text { Nahaw } \\
\text { a }\end{array}$ & $\begin{array}{l}\text { Surah } \\
\text { Al- } \\
\text { Ikhlash } \\
\text { Irama } \\
\text { Nahaw } \\
\text { a }\end{array}$ & 1 & 5 & 3 & 2 & 3 & $60 \%$ \\
\hline $\begin{array}{l}\text { Suara } \\
\text { Adzan } \\
\text { Irama } \\
\text { Manso } \\
\text { or Al- } \\
\text { Zahraa } \\
\text { ny }\end{array}$ & $\begin{array}{l}\text { Surah } \\
\text { Al- } \\
\text { Ikhlash } \\
\text { Irama } \\
\text { Manso } \\
\text { or }\end{array}$ & 1 & 5 & 4 & 1 & 4 & $80 \%$ \\
\hline
\end{tabular}


TECHSI: Vol. 10, No. 2, Oktober 2018

Hasil pengujian tabel 4.8 menunjukkan bahwa true detection pada masing-masing suara adzan sangat dipengaruhi oleh banyaknya sampel suara pelatihan.Hal ini terjadi karena sampel suara adzan dikenali jika sampel suara yang diuji mempunyai sampling pola suara yang mirip dengan sampling pola suara latih.Untuk mencari nilai presentasi kebenarannya, jumlah detection rate dibagi dengan jumlah suara pengujian dan kemudian dikali 100.

\section{Grafik Unjuk Kerja Sistem Pengenalan Nagham Adzan Melalui Suara}

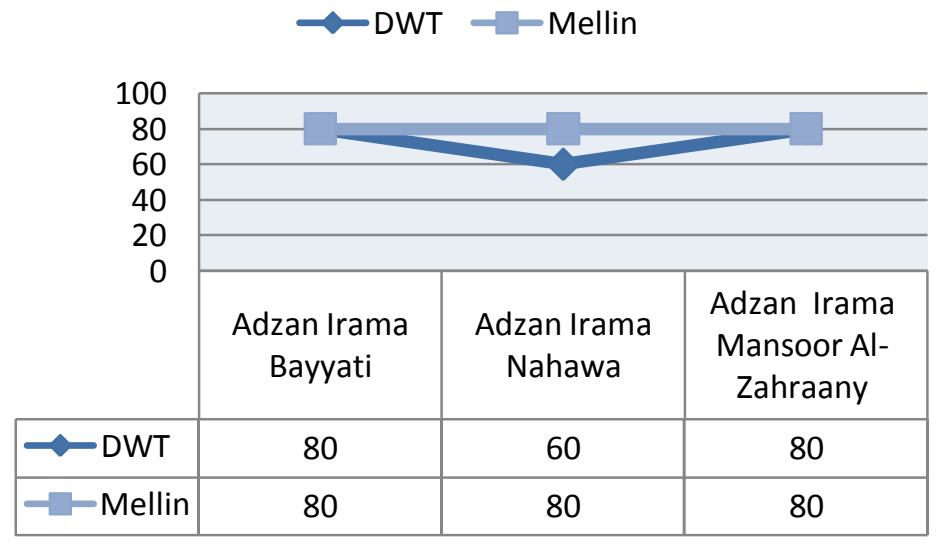

Gambar 3.5 Grafik Presentasi Perbandingan Algoritma Discrete Wavelet Transform dan Mellin Transform Pada Sistem Pengenalan Nagham Adzan melalui Suara

Pada gambar 4.36 Grafik mengilustrasikan seluruh tahap pelatihan dan pengujian diperoleh untuk Discrete Wavelet Transform nilai detection rate untuk adzan irama bayyati $=80 \%$, adzan irama nahawa $=60 \%$, adzan irama mansoor al-zahraany $=80 \%$ dan untuk Mellin Transform nilai detetion rate untuk adzan irama bayyati $=80 \%$, adzan irama nahawa $=80 \%$, adzan irama mansoor al-zahraany $=80 \%$

Sehingga dari semua perhitungan dapat disimpulkan bahwa transformasi yang paling banyak dalam mendeteksi pengenalan nagham suara adzan adalah Mellin Transform, karena nilai rata-rata kebenaran dari algoritma Discrete Wavelet Transform $=73,33 \%$ dan Mellin Transform $=80 \%$. 


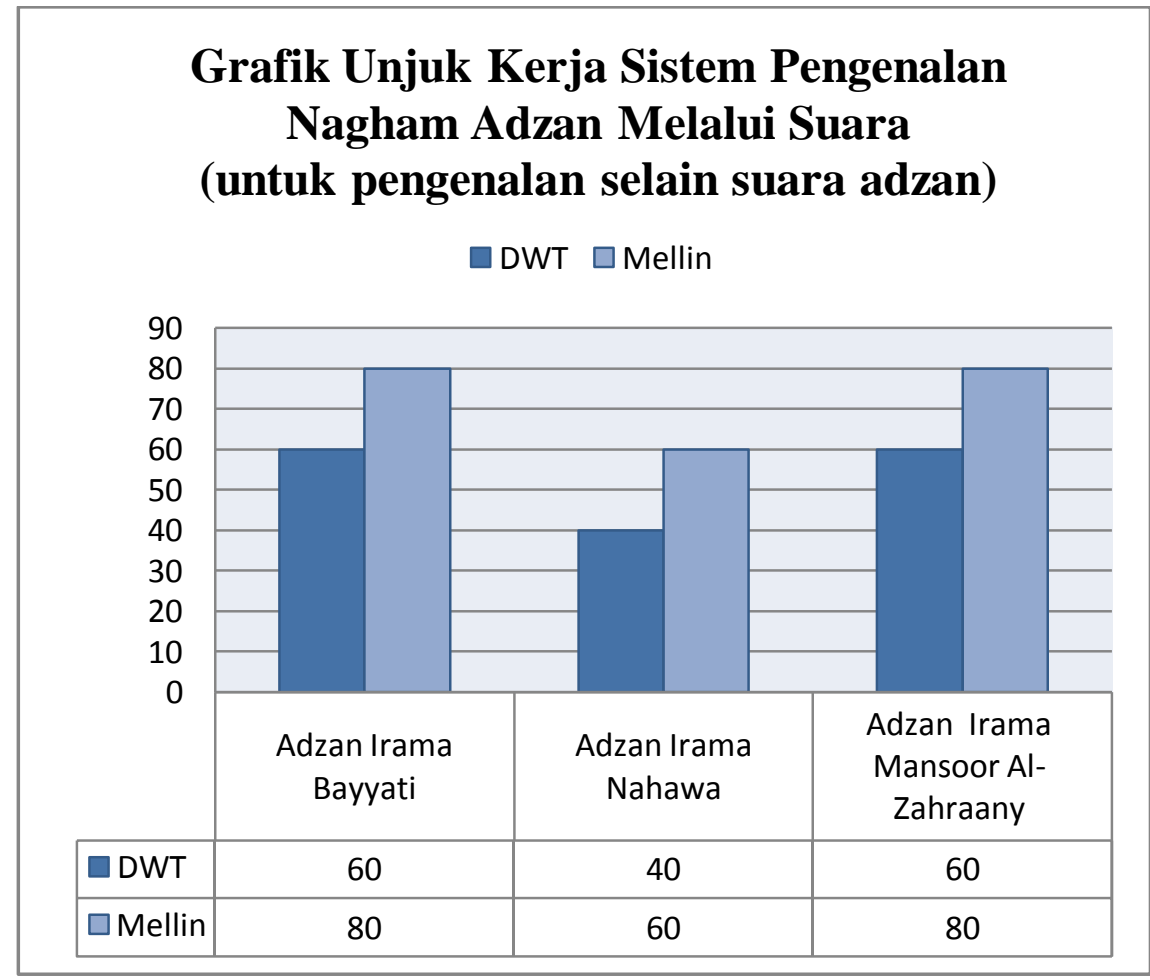

Gambar 3.6 Grafik Presentasi Perbandingan (Selain Suara Adzan) Algoritma Discrete Wavelet Transform dan Mellin Transform Pada Sistem Pengenalan Nagham Adzan melalui Suara

Pada gambar 3.6 Grafik mengilustrasikan seluruh tahap pelatihan dan pengujian diperoleh untuk Discrete Wavelet Transform nilai detection rate untuk adzan irama bayyati $=60 \%$, adzan irama nahawa $=40 \%$, adzan irama mansoor al-zahraany $=60 \%$ dan untuk Mellin Transform nilai detetion rate untuk adzan irama bayyati $=80 \%$, adzan irama nahawa $=60 \%$, adzan irama mansoor al-zahraany $=80 \%$

Sehingga dari semua perhitungan dapat disimpulkan bahwa transformasi yang paling banyak dalam mendeteksi pengenalan selain nagham suara adzan adalah Mellin Transform, karena nilai rata-rata kebenaran dari algoritma Discrete Wavelet Transform $=53,33 \%$ dan Mellin Transform $=73,33 \%$ 


\section{KESIMPULAN}

Hasil penelitian menunjukkan bahwa Perbandingan Kinerja Algoritma Discrete Wavelet Transform (DWT)danMellin Transform (DFT)untuk Sistem pengenalan nagham adzan melalui suara menggunakan algoritma DWTmemiliki kisaran deteksi kebenaransebesar 73,33\% Sedangkan dengan menggunakan algoritma Mellinmemiliki kisaran deteksi kebenaran sebesar 80 \% sehingga dari persentase menunjukkan bahwa dari segi hasil deteksi kebenaran tersebut menyatakan bahwa algoritma Mellin Transform (DST)lebih efisien.

Faktor faktor kemiripan maupun perbedaan sampel suara latih dan uji menjadi salah satu kelemahan pada sistem ini, karena sistem pengenalan nagham adzan melalui suara memiliki nilai sensitifitas yang sangat tipis sehingga deteksi tingkat kesalahan akan muncul.

\section{DAFTAR PUSTAKA}

Achmad Balza, Firdausy Kartika, 2013.Pengolahan Citra Digital Menggunakan Delphi. Yogyakarta: Andi.

AfrilliaYesy, 2014. Pengenalan Pola Huruf Jepang Katakana Menggunakan Transformasi Laplace Bilateral. Prodi Teknik Informatika Fakultas Teknik Universitas Malikussaleh. Reuleut-Aceh Utara.

Anharku, 2009.Flowchart. Jakarta: IlmuKomputer.Org.

A.S, Rosa dan M. Shalahuddin. 2013, RekayasaPerangkat Lunak Terstruktur dan Berorientasi Objek, Informatika, Bandung

Beni Hartanto, Analisa Bicubic Dan Bilinear Menggunakan Metode Discrete Wavelet Transform Pada Super Resolusi Program Studi Teknik Informatika, Universitas Dian Nuswantoro Jl. Nakula I No. 5-11, Semarang, INDONESIA

Dr. Rasyid bin Husain Abdul Karim. Materi Pengajian Setahun. Lentera : Jakarta. 2014

Fadlisyah, dkk. Pengolahan Suara. Yogyakarta : Graha Ilmu. 2013

Hasanudin, dkk. Bimbingan tilawatil quran : Jakarta. 2011

Haviluddin, 2011. MemahamiPenggunaan UML (Unified Modelling Language).

Jurnal Informatika Mulawarman, Volume VI, Nomor 1. Samarinda: FMIPAUniversitasMulawarman.http://www.scribd.com/mobile/doc/2071561 93/01-Jurnal-Informatika. Diakses pada tanggal 2 Desember 2016

Kadir Abdul, Dasar pengolahan citra dengan Delphi. Yogyakarta :Andi. 2013

Krisnawati, dkk. Transformasi Fourier Dan Transformasi Wavelet Pada Citra. Banten2012 
Muhaiminah, Khairul Al Kharim. Belajar Tilawatil Al-Quran : Yogyakarta. 2010

Muhammad Jawad Mughniyah, FIQIH Lima Mazhab. Malang :Aqwam. 2013

P.Flajolet, X.Gourdon and P.Dumas, 2011. Mellin transforms and asymptotics : Harmonic sums, Theoretical Computer Science

Putra Darma, Pengolahan Cita Digital, Yogyakarta : Andi. 2010

Rathore Sanjay, dkk., "Noise Reduction of Speech Signal using Wavelet Transform with Modified Universal Threshold," International Journal of Computer Applications, 2011.

Rendi Pradila Hab Sari, 20Desember 2013 makalah ResumeSeismologi "Introduction OfWavelet"Malang

Rustati Rahmi, Pengolahan Suara Menggunakan Transformasi Wavelet Dan Jaringan Syaraf Tiruan Untuk Pengenalan Pembicara,Agustus 2010

Sadiqa, Aulia., 2015, Perbandingan Metode Knuth Morris Pratt dan Metode Boyer Moore pada Aplikasi Kamus Istilah Kimia Berbasis Android, Tugas Akhir, Program Studi Teknik Informatika, Universitas Malikussaleh, Aceh Utara

V.D. Sharma, A.N. Rangari. 2014. Fourier-Finite Mellin Transform And Its Analytical Study. International Journal Of Applied Computational Science \&Mathematics. Volume 4, Number 1 (2014), Pp. 25-30

Widodo, P. P., dan Herlawati, 2011. Menggunakan UML. Informatika Bandung. Bandung. 